\title{
PENERAPAN MODEL PEMBELAJARAN LEARNING STARTS WITH A QUESTION UNTUK MENINGKATKAN HASIL BELAJAR IPA TEMA EKOSISTEM SISWA KELAS V UPT. SD NEGERI 22 BARINGIN
}

\author{
ENI ROSDA \\ enirosda22@gmail.com
}

\begin{abstract}
The right learning model is needed to achieve an active learning process, generally teachers at UPT. SD Negeri 22 Baringin is not right to use a learning model that should be in accordance with the teaching material. So that students in the class often feel bored and less enthusiastic about learning, which makes the classroom atmosphere passive and few students want to ask the teacher even though the material being taught has not been understood so that it affects learning outcomes. Given the problems that lead to unsatisfactory student learning outcomes, researchers are very careful in applying the learning model. Researchers try to use the learning model learning starts with a question. This study aims to determine teacher activities, student activities and student learning outcomes through the application of the learning model learning starts with a question. This research is a Classroom Action Research with the research subjects of class V UPT students. SD Negeri 22 Baringin. This research was conducted in two cycles, each of which included planning, implementing, observing and reflecting. Data obtained through research instruments, observation sheets, tests, and processed using a percentage formula. Based on the research results, it is known that: (1) Teacher activity with the application of the learning model starts with a question increased from cycle I only at $66.67 \%$ increased in cycle II to $83.33 \%$, (2) Student activity in cycle I was only $69.74 \%$ increase in cycle II to $82.95 \%$, (3) Classical student learning outcomes in cycle I only $65 \%$ increase in cycle II to $85 \%$ this means that most students complete their learning by applying the learning model learning starts with a question on the material on the relationship between living things in the ecosystem in class VUPT. SD Negeri 22 Baringin.
\end{abstract}

Keywords: Learning Outcomes, Learning Starts Model With a Question Science Lessons.

Abstrak: Model pembelajaran yang tepat sangat dibutuhkan untuk mencapai proses pembelajaran yang aktif, pada umumnya guru di UPT. SD Negeri 22 Baringin tidak tepat menggunakan model pembelajaran yang harusnya sesuai dengan materi ajar. Sehingga siswa di kelas sering merasakan jenuh dan kurang bergairah dalam belajar yang membuat suasana kelas cenderung pasif dan sedikit siswa yang mau bertanya pada guru meskipun materi yang diajarkan belum dipahami sehingga mempengaruhi hasil belajar. Mengingat persoalan yang berujung pada tidak memuaskannya hasil belajar siswa membuat peneliti sangat berhati-hati dalam menerapkan model pembelajaran. Peneliti mencoba menggunakan model pembelajaran learning starts with a question. Penelitian ini bertujuan untuk mengetahui aktivitas guru, aktivitas siswa serta hasil belajar siswa melalui penerapan model pembelajaran learning starts with a question. Penelitian ini merupakan Penelitian Tindakan Kelas dengan subjek penelitian siswa kelas V UPT. SD Negeri 22 Baringin. Penelitian ini dilakukan dua siklus masing-masing siklus meliputi perencanaan, pelaksanaan, observasi dan refleksi. Data diperoleh melalui instrumen penelitian, lembar observasi, tes, dan diolah menggunakan rumus persentase. Berdasarkan hasil penelitian diketahui bahwa: (1) Aktivitas guru dengan penerapan model pembelajaran learning starts with a question meningkat dari siklus I hanya pada 66,67\% meningkat pada siklus II menjadi 83,33\%, (2) Aktivitas siswa 
pada siklus I hanya pada 69,74\% meningkat pada siklus II menjadi $82,95 \%$, (3) Hasil belajar siswa secara klasikal pada siklus I hanya 65\% meningkat pada siklus II menjadi $85 \%$ ini berarti sebagian besar siswa tuntas belajarnya dengan diterapkan model pembelajaran learning starts with a question pada materi hubungan makhluk hidup dalam ekosistem di kelas V UPT. SD Negeri 22 Baringin.

Kata kunci: Hasil Belajar, Model Learning Starts With a Question Pelajaran IPA.

\section{A. Pendahuluan}

Proses belajar mengajar merupakan bagian terpenting dalam proses pendidikan yang di dalamnya terdapat guru sebagai pengajar dan siswa yang sedang belajar. Proses belajar mengajar merupakan suatu proses yang mengandung serangkaian perbuatan guru dan siswa atas dasar hubungan timbal balik yang berlangsung melalui hubungan edukatif untuk mencapai tujuan tertentu. Sebelum melakukan proses belajar mengajar setiap guru harus merancang sebuah model pembelajaran yang bisa memberi perubahan yang lebih baik lagi dari sebelumnya agar tercapai nilai yang tinggi atau paling tidak tercapai nilai ketuntasan minimal siswa. Model pembelajaran yang dapat diterapkan oleh para guru sangat beragam. Model pembelajaran adalah suatu pola atau langkah-langkah pembelajaran tertentu yang diterapkan agar tujuan atau kompetensi dari hasil belajar yang diharapkan akan cepat dapat dicapai dengan lebih efektif dan efisien. Dalam proses belajar mengajar guru dan model pembelajaran sangat berperan penting guna untuk mencapai tujuan yang ingin dicapai khususnya dalam pelajaran IPA. Model-model yang digunakan oleh guru harus sesuai dengan materi yang akan disampaikan sehingga akan memudahkan siswa dalam memahami materi yang akan diberikan oleh guru. Meningkatnya pemahaman siswa dalam memahami suatu materi pelajaran sangat dipengaruhi oleh model yang digunakan.

Selama ini model pembelajaran yang digunakan oleh guru-guru dalam proses pembelajaran adalah model pembelajaran konvensional yang hanya meliputi siswa datang, duduk, menulis materi, yang telah dituliskan oleh guru dipapan tulis, mendengarkan guru menjelaskan materi dan mengerjakan tugas. Seorang anak akan berhasil dalam proses belajar apabila pada dirinya ada keinginan untuk belajar. Adanya keinginan tersebut, akan membangkitkan anak untuk mempelajari suatu materi yang akan diajarkan kepadanya. Anak di dalam dirinya mempunyai mental, emosi dan kapasitas untuk mencapai tujuannya. Keseluruhan sistem pendidikan sangat banyak mengarah pada anak, dengan proses belajar mengajar dapat menolong anak mempelajari bahan pelajaran. Salah satu alternatif yang dapat digunakan dalam pembelajaran adalah model pembelajaran learning starts with a question yang berarti ikut serta atau terlibat dalam mengajukan pertanyaan-pertanyaan, mencari informasi dan melakuakn penyelidikan. Model pembelajaran learning starts with a question menekan mareka bertanya tentang materi pelajaran sebelum ada penjelasan dari pengajar. Model ini dapat menggugah peserta didik untuk mencapai kunci belajar, yaitu bertanya.

Menurut Istarani (2012: 207) Model pembelajaran learning starts with a question adalah suatu cara untuk membuat peserta didik belajar secara aktif dengan membuat mareka bertanya tentang materi pebelajaran sebelum ada penjelasan dari pengajar. Pertanyaan akan mengundang siswa untuk berfikir terhadap materi ajar yang akan disampaikan. Adanya keinginan bertanya berarti siswa semakin tinggi rasa ingin tahunya tentang pelajaran tersebut dan pembelajaran akan lebih hidup. Model pembelajaran learning starts with a question memiliki kelebihan dan kekurangan, 
salah satu kelebihan adalah dengan siswa bertanya maka akan mengundang siswa untuk berpikir terhadap materi ajar yang akan disampaikan, meningkatkan aktifitas belajar siswa sebab kadang-kadang ia buka buku untuk mencari jawaban yang diinginkan, penyajian materi akan semakin mendalam, karena materi disampaikan melalui pertanyaan yang dilontarkan siswa, pembelajaran akan lebih hidup karana materi disampaikan sesuai dengan keinginan dan kemampuan peserta didik. Kekurangan dari model ini adalah siswa kurang terbiasa membuat pertanyaan yang baik dan benar, siswa tidak tahu apa yang mau ditanyakan kepada gurunya, pertanyaan yang dibuat adakalanya hanya bersifat sekedar dibuat-buat saja (yang penting ada pertanyaannya dari pada tidak bertanya).

IPA merupakan salah satu ilmu yang mempunyai peran sangat besar dalam perkembanagan ilmu penegetahuan dan teknologi, oleh karena itu berbagai cara dilakukan untuk meningkatkan mutu pendidikan IPA. Perkembangan ilmu pengetahuan alam tidak ditunjukkan oleh kemampuan fakta saja melainkan timbul dan berkembangnya karya ilmiah. Dalam proses pembelajaran siswa tidak hanya berperan sebagai penerima pelajaran melalui penjelasan guru tetapi siswa dapat melatih daya nalar dalam memecahkan masalah sehingga mareka menemukan sendiri inti dari materi tersebut. Berdasarkan hasil pengalaman saya mengajar di kelas V UPT. SD Negeri 22 Baringin Kecamatan Lima Kaum Kabupaten Tanah Datar pada saat saya memulai pembelajaran masih ada sebagian siswa yang belum siap belajar padahal saya memulai pembelajaran dengan penuh semangat dan ceria, hal itu bisa membuat sebuah pembelajaran tersebut tidak sesuai dengan yang kita inginkan padahal kita menginginkan siswa siap belajar saat menit pertama sampai akhir pembelajaran.

Sedangkan dalam pembelajaran IPA siswa dituntun untuk mengeluarkan seluruh kemampuan yang dimiliki, guna mencapai hasil belajar yang sesuai dengan tujuan pembelajaran. Selain itu dari hasil diskusi dengan guru juga terungkap bahwa selain guru hanya menggunakan metode ceramah dan tanya jawab, dalam proses pembelajaran guru hanya mengajar untuk menuntaskan atau mengejar materi dalam silabus supaya cepat selesai tanpa melihat dampak pada siswa. Kenyataannya, kecepatan menuntaskan materi tidak membuat hasil belajar siswa menjadi lebih baik, bahkan menghasilkan hasil belajar yang rendah. Rendahnya hasil belajar IPA tidak hanya pada aspek kemampaun untuk mengerti pelajaran IPA sebagai pengetahuan, tetapi juga aspek rendahnya sikap terhadap IPA. Berdasarkan uraian yang telah dipaparkan di atas, maka yang menjadi permasalahan adalah proses belajar mengajar yang terjadi di UPT. SD Negeri 22 Baringin Besar kurang sesuai dengan apa yang diharapkan. Oleh karena itu, penulis mencoba untuk menerapkan model pembelajaran learning starts with a question pada tingkat SD dengan melakukan penelitian dengan judul "Penerapan Model Pembelajaran Learning Starts With A Question untuk Meningkatkan Hasil Belajar IPA Tema Ekosistem Siswa Kelas V UPT. SD Negeri 22 Baringin".

Saya menerapkan model pembelajara learning starts with a question supaya siswa dapat terlatih melakukan kegiatan yang dilakukan para ilmuwan dalam memperoleh ilmu pengetahuan untuk menemukan konsep-konsep serta menerapkannya dalam kehidupan sehari-hari. Siswa dapat menerima banyak hal dari penerapan model pembelajaran learning starts with a question yang akan mengiringi siswa lebih aktif dalam proses pembelajaran dan lebih jauhnya dapat mempengaruhi peningkatan hasil belajar.

Fokus rumusan masalah penelitian ini adalah bagaimana proses pembelajaran menggunakan model pembelajaran learning starts with a question untuk EISSN 2657-0289 Lembaga Penelitian dan Penerbitan Hasil Penelitian Ensiklopedia $\quad 39$ 
meningkatkan hasil belajar siswa pada mata pelajaran IPA Tema Ekosistem kelas V UPT. SD Negeri 22 Baringin. Rumusan masalah di atas dapat dijabarkan dalam beberapa sub fokus berikut: 1) Bagaimanakah aktivitas guru dalam mengelola pembelajaran dengan penerapan model pembelajaran learning starts with a question dalam meningkatkan hasil belajar siswa pada pembelajaran IPA Tema Ekosistem di kelas V UPT. SD Negeri 22 Baringin? 2) Bagaimanakah aktivitas siswa dalam proses pembelajaran dengan penerapan model learning starts with a question dalam meningkatkan hasil belajar siswa pada pembelajaran IPA Tema Ekosistem di kelas V UPT. SD Negeri 22 Baringin? 3) Bagaimanakah peningkatan hasil belajar siswa pada pembelajaran IPA Tema Ekosistem dengan penerapan model pembelajaran learning starts with a question di kelas V UPT. SD Negeri 22 Baringin?

\section{B. Metodologi Penelitian}

Rancangan penelitian dalam penelitian ini adalah dengan menggunakan bentuk penelitian tindakan kelas. Dari namanya sudah menunjukkan isi yang terkandung di dalamnya, yaitu sebuah kegiatan penelitian yang dilakukan di kelas. Menurut Arikunto ( 2014: 2) penelitian tindakan kelas secara harfiah yaitu penelitian itu sendiri mempunyai arti yaitu suatu kegiatan mencermati suatu objek dengan menggunakan cara dan aturan metodologi tertentu untuk memperoleh data atau informasi yang bermanfaat dalam meningkatkan mutu suatu hal yang menarik minat dan penting bagi peneliti. Tindakan yaitu sesuatu gerak kegiatan yang sengaja dilakukan dengan tujuan tertentu. Dalam penelitian berbentuk rangkaian siklus kegiatan untuk siswa. Kelas adalah sekelompok siswa yang dalam waktu yang sama, menerima pelajaran yang sama dari guru yang sama pula. Menggabungkan batasan pengertian tiga kata inti yaitu penelitian, tindakan, dan kelas, segera dapat disimpulkan bahwa penelitian tindakan kelas merupakan suatu pencermatan terhadap kegiatan belajar berupa sebuah tindakan yang sengaja dimunculkan dan terjadi di sebuah kelas secara bersama-sama. Tindakan tersebut diberikan oleh guru atau dengan arahan dari guru yang dilakukan oleh siswa. Lokasi penelitian yaitu tempat yang digunakan dalam melakukan penelitian untuk memperoleh data yang diinginkan. Penelitian ini bertempat di UPT. SD Negeri 22 Baringin Kecamatan Lima Kaum Kabupaten Tanah Datar, alasan saya pilih SD tersebut karena berdasarkan observasi yang mana di sekolah ini karakteristik peserta didik yang bermacam-macam membutuhkan pembelajaran yang bisa membuat mareka lebih aktif dan nyaman dalam belajar. Subjek penelitian dalam penelitian ini yaitu siswa kelas V UPT. SD Negeri 22 Baringin Kecamatan Lima Kaum Kabupaten Tanah Datar yang berjumlah 20 orang siswa, yang terdiri dari 10 pesrta didik lakilaki dan 10 pesrta didik perempuan.

\section{Hasil dan Pembahasan Deskripsi Kondisi Awal}

Data awal hasil belajar peserta didik tema Ekosistem melalui tes pratindakan (pre test), dari 20 siswa yang mengikuti pre test menunjukan hasil dibawah ini: 
Tabel Hasil Belajar Peserta Didik Pre - Test ( Pra Siklus)

\begin{tabular}{|c|c|c|c|c|c|}
\hline \multirow[b]{2}{*}{ No } & \multirow[b]{2}{*}{ Nama Peserta Didik } & \multirow[b]{2}{*}{ KKM } & \multirow[b]{2}{*}{ Nilai } & \multicolumn{2}{|c|}{ Ketuntasan } \\
\hline & & & & Ya & Tidak \\
\hline 1 & Aldo Putra Pratama & 75 & 70 & & $\sqrt{ }$ \\
\hline 2 & Asilah Hanania Paragus & 75 & 40 & & $\sqrt{ }$ \\
\hline 3 & \begin{tabular}{|l} 
Ayunda Tasya Agustin \\
\end{tabular} & 75 & 80 & $\sqrt{ }$ & \\
\hline 4 & Aziz Dwi Putra & 75 & 90 & $\sqrt{ }$ & \\
\hline 5 & Dzaky Dhimas Trianto & 75 & 70 & & $\sqrt{ }$ \\
\hline 6 & Felin Isra Roza & 75 & 80 & $\sqrt{ }$ & \\
\hline 7 & Galang Germawan & 75 & 50 & & $\sqrt{ }$ \\
\hline 8 & Idris Alamsyah & 75 & 80 & $\sqrt{ }$ & \\
\hline 9 & IIma Tri Handayani & 75 & 60 & & $\sqrt{ }$ \\
\hline 10 & Intan & 75 & 80 & $\sqrt{ }$ & \\
\hline 11 & Jenny Roya Afandi & 75 & 70 & & $\sqrt{ }$ \\
\hline 12 & Muhammad Haidar Lathif & 75 & 40 & & $\sqrt{ }$ \\
\hline 13 & Muhammad Rauf Maros & 75 & 80 & $\sqrt{ }$ & \\
\hline 14 & $\begin{array}{l}\text { Muhammad Sentanu Al } \\
\text { Bukhori }\end{array}$ & 75 & 50 & & $\sqrt{ }$ \\
\hline 15 & Naura Ceko Putri & 75 & 80 & $\sqrt{ }$ & \\
\hline 16 & Rahmi & 75 & 80 & $\sqrt{ }$ & \\
\hline 17 & Sastra Aditya & 75 & 30 & & $\sqrt{ }$ \\
\hline 18 & Syavilda Rahma Dessytra & 75 & 70 & & $\sqrt{ }$ \\
\hline 19 & Vathumay Nova & 75 & 80 & $\sqrt{ }$ & \\
\hline 20 & Pariel Mahendra & 75 & 50 & & $\sqrt{ }$ \\
\hline \multicolumn{3}{|c|}{ Jumlah } & 1330 & 9 & 11 \\
\hline \multicolumn{3}{|c|}{ Nilai rata-rata } & 66,5 & & \\
\hline \multicolumn{4}{|c|}{ Presentase } & $45 \%$ & $55 \%$ \\
\hline
\end{tabular}

Dari data tabel di atas, dapat dilihat nilai rata-rata kelas adalah 66,5 peserta didik yang berhasil mencapai KKM atau mendapat nilai $\geq 75$ adalah 9 siswa (45\%) dan peserta didik yang belum berhasil mencapai KKM atau mendapatkan nilai $<75$ adalah 11 siswa ( $55 \%$ ). Berdasarkan hasil pre test maka peneliti dan observer (teman sejawat) sepakat melakukan perbaikan berupa penelitian tindakan kelas untuk meningkatkan hasil belajar peserta didik pada tema Ekosistem. Rencana perbaikan ini model pembelajaran learning starts with a question pada materi hubungan makhluk hidup dalam ekosistem yang diharapkan dapat meningkatkan hasil belajar peserta didik dalam proses pembelajaran sehingga hasil belajar juga meningkat. Selain itu,

Deskripsi Hasil Penelitian Siklus I. Siklus I dilaksanakan dalam empat tahap yaitu: perencanaan, pelaksanaan, observasi dan refleksi. Tes diberikan oleh peneliti kepada peserta didik disetiap akhir proses pembelajaran. Tes yang diberikan terdiri dari 10 soal berbentuk choice. Hasil tes belajar peserta didik yang diperoleh pada siklus I pada materi hubungan makhluk hidup dalam ekosistem dapat dilihat pada tabel berikut ini:

Tabel Hasil Belajar Peserta Didik pada Materi Hubungan Makhluk Hidup dalam Ekosistem Siklus I

\begin{tabular}{|c|c|c|c|c|c|}
\hline \multirow[b]{2}{*}{ No } & \multirow[b]{2}{*}{ Nama Peserta Didik } & \multirow[b]{2}{*}{ KKM } & \multirow[b]{2}{*}{ Nilai } & \multicolumn{2}{|c|}{ Ketuntasan } \\
\hline & & & & $\mathrm{Ya}$ & Tidak \\
\hline 1 & Aldo Putra Pratama & 75 & 80 & $\sqrt{ }$ & \\
\hline 2 & Asilah Hanania Paragus & 75 & 50 & & $\sqrt{ }$ \\
\hline 3 & Ayunda Tasya Agustin & 75 & 80 & $\sqrt{ }$ & \\
\hline 4 & Aziz Dwi Putra & 75 & 100 & $\sqrt{ }$ & \\
\hline 5 & \begin{tabular}{|l} 
Dzaky Dhimas Trianto \\
\end{tabular} & 75 & 80 & $\sqrt{ }$ & \\
\hline 6 & Felin Isra Roza & 75 & 80 & $\sqrt{ }$ & \\
\hline 7 & Galang Germawan & 75 & 60 & & $\sqrt{ }$ \\
\hline 8 & Idris Alamsyah & 75 & 80 & $\sqrt{ }$ & \\
\hline 9 & Ilma Tri Handayani & 75 & 70 & & $\sqrt{ }$ \\
\hline 10 & Intan & 75 & 90 & $\sqrt{ }$ & \\
\hline 11 & \begin{tabular}{|l} 
Jenny Roya Afandi \\
\end{tabular} & 75 & 80 & $\sqrt{ }$ & \\
\hline 12 & Muhammad Haidar Lathif & 75 & 50 & & $\sqrt{ }$ \\
\hline 13 & \begin{tabular}{|l} 
Muhammad Rauf Maros \\
\end{tabular} & 75 & 80 & $\sqrt{ }$ & \\
\hline 14 & $\begin{array}{l}\text { Muhammad Sentanu Al } \\
\text { Bukhori }\end{array}$ & 75 & 60 & & $\sqrt{ }$ \\
\hline 15 & \begin{tabular}{|l} 
Naura Ceko Putri \\
\end{tabular} & 75 & 80 & $\sqrt{ }$ & \\
\hline 16 & \begin{tabular}{|l} 
Rahmi \\
\end{tabular} & 75 & 90 & $\sqrt{ }$ & \\
\hline 17 & \begin{tabular}{|l|} 
Sastra Aditya \\
\end{tabular} & 75 & 50 & & $\sqrt{ }$ \\
\hline 18 & \begin{tabular}{|l} 
Syavilda Rahma Dessytra \\
\end{tabular} & 75 & 80 & $\sqrt{ }$ & \\
\hline 19 & \begin{tabular}{|l} 
Vathumay Nova \\
\end{tabular} & 75 & 80 & $\sqrt{ }$ & \\
\hline 20 & Pariel Mahendra & 75 & 60 & & $\sqrt{ }$ \\
\hline \multicolumn{2}{|c|}{ Jumlah } & & 1480 & 13 & 7 \\
\hline \multirow{2}{*}{\multicolumn{2}{|c|}{ Nilai rata-rata }} & & 74 & & \\
\hline & & & & $65 \%$ & Se \\
\hline
\end{tabular}


Berdasarkan tabel di atas terlihat bahwa nilai peserta didik dengan menggunakan model pembelajaran learning starts with a question pada materi hubungan makhluk hidup dalam ekosistem, mencapai (65\%) dan ketuntasan belajar secara klasikal sebanyak 13 peserta didik, sedangkan sebanyak 7 peserta didik atau (35\%) belum mencapai ketuntasan belajar secara klasikal.

Deskripsi Hasil Penelitian Siklus II. Pelaksanaan penelitian siklus II dilaksanakan dalam empat tahap yaitu: perencanaan, pelaksanaan, observasi dan refleksi. Tes diberikan oleh peneliti kepada siswa disetiap akhir proses pembelajaran. Tes yang diberikan terdiri dari 10 soal berbentuk choice. Hasil tes belajar siswa yang diperoleh pada siklus II pada materi hubungan makhluk hidup dalam ekosistem dapat dilihat pada tabel berikut ini:

Tabel Hasil Belajar Peserta Didik pada Materi Hubungan Makhluk Hidup dalam Ekosistem Siklus II

\begin{tabular}{|c|c|c|c|c|c|}
\hline \multirow[b]{2}{*}{ No } & \multirow[b]{2}{*}{ Nama Peserta Didik } & \multirow[b]{2}{*}{ KKM } & \multirow[b]{2}{*}{ Nilai } & \multicolumn{2}{|c|}{ Ketuntasan } \\
\hline & & & & $\mathrm{Ya}$ & Tidak \\
\hline 1 & Aldo Putra Pratama & 75 & 100 & $\sqrt{ }$ & \\
\hline 2 & Asilah Hanania Paragus & 75 & 60 & & $\sqrt{ }$ \\
\hline 3 & Ayunda Tasya Agustin & 75 & 80 & $\sqrt{ }$ & \\
\hline 4 & Aziz Dwi Putra & 75 & 100 & $\sqrt{ }$ & \\
\hline 5 & Dzaky Dhimas Trianto & 75 & 80 & $\sqrt{ }$ & \\
\hline 6 & Felin Isra Roza & 75 & 90 & $\sqrt{ }$ & \\
\hline 7 & Galang Germawan & 75 & 80 & $\sqrt{ }$ & \\
\hline 8 & Idris Alamsyah & 75 & 80 & $\sqrt{ }$ & \\
\hline 9 & IIma Tri Handayani & 75 & 80 & $\sqrt{ }$ & \\
\hline 10 & Intan & 75 & 100 & $\sqrt{ }$ & \\
\hline 11 & Jenny Roya Afandi & 75 & 80 & $\sqrt{ }$ & \\
\hline 12 & Muhammad Haidar Lathif & 75 & 70 & & $\sqrt{ }$ \\
\hline 13 & Muhammad Rauf Maros & 75 & 90 & $\sqrt{ }$ & \\
\hline 14 & $\begin{array}{l}\text { Muhammad Sentanu Al } \\
\text { Bukhori }\end{array}$ & 75 & 80 & $\sqrt{ }$ & \\
\hline 15 & Naura Ceko Putri & 75 & 80 & $\sqrt{ }$ & \\
\hline 16 & Rahmi & 75 & 100 & $\sqrt{ }$ & \\
\hline 17 & Sastra Aditya & 75 & 50 & & $\sqrt{ }$ \\
\hline 18 & Syavilda Rahma Dessytra & 75 & 90 & $\sqrt{ }$ & \\
\hline 19 & Yathumay Nova & 75 & 80 & $\sqrt{ }$ & \\
\hline 20 & Pariel Mahendra & 75 & 80 & $\sqrt{ }$ & \\
\hline \multicolumn{2}{|c|}{ Jumlah } & & 1650 & 17 & 3 \\
\hline \multicolumn{2}{|c|}{ Nilai rata-rata } & & 82,50 & & \\
\hline \multicolumn{4}{|c|}{ Presentase } & $85 \%$ & $15 \%$ \\
\hline
\end{tabular}

Berdasarkan tabel di atas terlihat bahwa nilai rata-rata siswa mencapai (85\%) dan hasil belajar siswa secara klasikal sebanyak 17 siswa yang tuntas, sedangkan sebanyak 3 siswa atau (15\%) belum mencapai ketuntasan belajar secara klasikal.

\section{Pembahasan Hasil Penelitian}

Penelitian ini adalah penelitian tindakan kelas (action recearch). Action recearch adalah kegiatan penelitian untuk mendapatkan kebenaran dan mamfaat dengan cara melakukan tindakan secara kolaboratif. Muslim (2009: 9 ) Tujuan dari penelitian tindakan kelas salah satunya adalah memperbaiki dan meningkatkan kondisi serta kualitas pembelajaran di kelas. Penelitian ini dilakukan untuk melihat aktivitas kemampuan guru dan aktivitas siswa serta hasil belajar siswa melalui penerapan

$42 \quad$ Lembaga Penelitian dan Penerbitan Hasil Penelitian Ensiklopedia $\quad$ EISSN 2657-0289 PISSN 2657-0297 
model pembelajaran learning starts with a question pada materi hubungan makhluk hidup dalam ekosistem. Data ini diperoleh dari hasil pengamatan aktivitas kemampuan guru dan aktivitas siswa serta dari hasil belajar siswa. Hasil analisis data terhadap aktivitas kemampuan guru dan aktivitas siswa diperoleh data bahwa pembelajaran yang berlangsung telah memenuhi kriteria pembelajaran dalam penerapan model pembelajaran learning Starts With a Question.

Aktivitas Guru Selama Proses Pembelajaran Dengan Menerapkan Model Learning Starts With a Question. Berdasarkan hasil penelitian yang telah diperoleh tentang aktivitas guru selama dua siklus terlihat mengalami peningkatan. Hal ini dapat dilihat dari skor rata-rata yang diperoleh pada siklus I sebesar 66,67\% (kategori cukup) dan siklus II sebesar 83,33\% (kategori baik). Untuk lebih jelas dapat dilihat pada gambar diagram tabung berikut: Diagram Tabung Nilai Rata-Rata Aktivitas Mengajar Guru. Dari gambar diagram tabung 1 dapat disimpulkan bahwa aktivitas guru dalam pengelolaan pembelajaran dengan menerapkan model learning starts with a question pada materi hubungan makhluk hidup dalam ekosistem berada pada kategori baik. Hal ini disebabkan karena aktivitas guru dalam melaksanakan pembelajaran pada kegiatan awal, inti dan akhir sudah terlaksana sesuai dengan RPP, tercukupinya sarana dan prasarana yang dapat menunjang proses pembelajaran baik yang berupa buku paket dan model/media pembelajaran lainnya.

Aktivitas Peserta Didik Selama Proses Pembelajaran Dengan Menerapkan Model Learning Starts With a Questio. Hasil analisis data aktivitas peserta didik selama mengikuti pembelajaran dengan penerapan model learning starts with a question selama dua siklus adalah pada siklus I diperoleh nilai persentase $69,74 \%$ (kategori cukup) dan siklus II diperoleh nilai 82,95\% (kategori baik). Hal ini membuktikan bahwa dalam menerapkan model learning starts with a question, guru berusaha untuk memaksimalkan aktivitas peserta didik dalam pembelajaran agar terus meningkat. Dengan demikian aktivitas peserta didik dengan penerapan model learning starts with a question mengalami peningkatan. Berdasarkan hasil analisis data terlihat adanya peningkatan pada aktivitas peserta didik dengan penerapan model learning starts with a question. Hal ini terihat pada saat peserta didik secara aktif mempelajari teks bacaan, mencari kata/pengertian yang tidak dimengerti/dipahami, menulis pertanyaan dan juga peserta didik secara aktif mencari jawaban dari pertanyaan kelompok lain. Data nilai rata-rata setiap siklus dapat dilihat pada gambar diagram tabung berikut: Diagram Tabung Nilai Rata-Rata Aktivitas Belajar Peserta Didik. Dari gambar diagram tabung dapat disimpulkan bahwa aktivitas peserta didik dalam mengikuti pembelajaran dengan menerapkan model learning starts with a question pada materi hubungan makhluk hidup dalam ekosistem berada pada kategori baik. Hal ini disebabkan karena aktivitas peserta didik dalam mengikuti pembelajaran pada kegiatan awal, inti dan akhir sudah terlaksana sesuai dengan RPP dan langkah-langkah model pembelajaran.

Hasil Belajar Peserta Didik Selama Proses Pembelajaran Dengan Menggunakan Model Learning Starts With a Question Hasil penelitian yang telah dilakukan dapat dilihat dari nilai evaluasi yang telah diberikan kepada peserta didik setelah proses belajar mengajar yang berupa soal pilihan ganda. Kemudian hasil evaluasi peserta didik diolah kedalam tabel distribusi frekuensi dengan menggunakan rumus persentase. Data diperoleh dari hasil tes yang diberikan pada setiap siklus yang terdiri dari dua siklus. Hasil tes yang dicapai pada tiap-tiap tes dianalisis ketuntasan belajarnya, baik secara individual maupun klasikal. Nilai ketuntasan 
kriteria minimal (KKM) untuk materi hubungan makhluk hidup dalam ekosistem yang telah ditentukan yaitu 75. Apabila nilai/skor yang diperoleh secara individual mencapai $75 \%$ atau secara klasikal $80 \%$ maka pembelajaran tersebut dikategorikan tuntas. Berdasarkan data yang terkumpul dan hasil analisis yang diperoleh dari soal post test menunjukkan bahwa adanya peningkatan hasil belajar peserta didik dari yang sebelumnya yaitu pada siklus I hanya 13 peserta didik yang tuntas atau (65\%), sedangkan 7 peserta didik tidak tuntas atau (35\%). Meningkat disiklus II yaitu 17 peserta didik tuntas atau (85\%), sedangkan 3 peserta didik atau (15\%) tidak tuntas.

Meningkatnya hasil belajar peserta didik pada siklus II karena pada awal pembelajaran peserta didik dengan baik dan benar menjawab pertanyaan-pertanyaan yang dilemparkan guru. Pada kegiatan inti peserta didik sangat baik dalam mempelajari teks bacaan, peserta didik dengan sangat teliti menandai bagian bacaan yang tidak dipahaminya, setiap kelompok sangat baik membacakan poin-poin penting yang sudah ditandai tadi dan peserta didik pada kelompok lain menanggapinya yaitu memberi jawaban mengenai poin-poin yang tidak kelompok itu ketahui. Hal lainnya yaitu peserta didik bisa atau mampu menuliskan pertanyaan-pertanyaan pada lembar kerja peserta didik dengan baik, bisa menjawab pertanyaan-pertanyaan yang dituliskan oleh kelompok lain dengan baik, peserta didik sangat baik dalam berdiskusi sebelum menjawab soal. Hal-hal lainnya yang membuat hasil belajar peserta didik meningkat yaitu pada kegiatan penutup peserta didik berani bertanya kepada guru yang belum dipahami, peserta didik bisa menarik kesimpulan pembelajaran dengan baik, peserta didik dengan baik dan benar menjawab pertanyaan dari guru, peserta didik mendengar kesimpulan pembelajaran yang disampaikan guru dengan baik, dan peserta didik membaca do'a sebelum mengakhiri pembelajaran dengan sangat baik.

Sesuai dengan teori belajar tuntas, maka seorang peserta didik dipandang tuntas belajar jika ia mampu menyelesaikan, menguasai kompetensi atau mencapai tujuan pembelajaran minimal $75 \%$ dari seluruh tujuan pembelajaran. sedangkan keberhasilan kelas dapat dilihat dari jumlah peserta didik yang mampu menyelesaikan atau mencapai sekurang-kurangnya $80 \%$ dari jumlah peserta didik yang ada dikelas tersebut. Data nilai rata-rata disetiap siklus dapat dilihat pada gambar diagram tabung berikut: Diagram Tabung Persentase Ketuntasan Haisl Belajar Peserta Didik.

Berdasarkan dagram tabung tersebut maka penerapan model pembelajaran learning starts with a question sudah berhasil, karena secara keseluruhan dari jumlah siswa 20 orang sudah mampu menyelesaikan soal-soal, mencapai indikator, dan tujuan pembelajaran pada materi hubungan makhluk hidup dalam ekosistem. Berdasarkan hasil penelitian yang telah dilakukan penerapan model pembelajaran learning starts with a question didalam pembelajaran IPA pada materi hubungan makhluk hidup dalam ekosistem dapat meningkatkan pencapaian hasil belajar siswa.

\section{Penutup}

Berdasarkan penelitian yang telah dilaksanakan, maka dapat disimpulkan sebagai berikut: 1) Aktivitas guru dalam mengelola pembelajaran dengan penerapan model pembelajaran learning starts with a question materi hubungan makhluk hidup dalam ekosistem pada siklus I berada dalam kategori cukup $(66,67 \%)$ dan meningkat pada siklus II menjadi baik yaitu (83,33\%). 2) Aktivitas peserta didik dalam proses pembelajaran dengan penerapan model learning starts with a question materi hubungan makhluk hidup dalam ekosistem pada siklus I berada dalam kategori cukup 
$(69,74 \%)$ dan meningkat pada siklus II menjadi baik (82,95\%). 3) Hasi belajar melalui penerapan model learning starts with a question materi hubungan makhluk hidup dalam ekosistem pada siklus I mencapai (65\%), sedangkan siklus II meningkat menjadi (85\%).

\section{Daftar Pustaka}

Arikunto Suharsimi, 2014. Penelitian Tindakan Kelas, Jakarta : Bumi Aksara.

Dewi Wijayanti Murwani, 2014. Tematik Terpadu, (Sidoarjo: PT. Masmedia ana Pustaka.

Depdiknas, 2006. Bunga Rampai Keberhasilan Guru dalam Pembelajaran, Jakarta: Depdiknas.

Hamalik, Oemar, 2000. Psikologi Belajar dan Mengajar. Bandung: PT Sinar Baru Algensindo.

Istarani, 2012. 58 Model Pembelajaran Inovatif, Medan: Media Persada.

Imron Ali, 2012. Manajemen Peserta Didik Berbasis Sekolah, Jakarta: PT Bumi Aksara.

Muslim Masnur, 2009. PTK itu Mudah, Bandung: Remaja Rosyda Karya.

Nazir Mohd, 2005. Metode Penelitian, Cet. 1, Jakarta: Ghalia Indonesia.

Slameto, 2003. Belajar dan Faktor-Faktor yang Mempengaruhinya, Jakarta:Rineka Cipta.

Sudjana, Nana. 2004. Penilaian Hasil proses Belajar Mengajar. Bandung : PT Remaja Rosdakarya.

Sukardi, 2004. Metode Penelitian Kompetensi dan Prakteknya, Jakarta: Bumi Aksara.

Wahidmurni, dkk, 2010. Evaluasi Pembelajaran Kompetensi dan Praktik, Yogyakarta:

Nuha Letera 